\title{
SOME CONSIDERATION ON VOMERINE TEETH AND VOMERINE PROTUBERANCE IN THE GOBIID FISH
}

\author{
$\operatorname{AUTHOR}(\mathrm{S})$ : \\ Yanagisawa, Yasunobu
}

\section{CITATION:}

Yanagisawa, Yasunobu. SOME CONSIDERATION ON VOMERINE TEETH AND VOMERINE PROTUBERANCE IN THE GOBIID FISH. PUBLICATIONS OF THE SETO MARINE BIOLOGICAL LABORATORY 1977, 24(1-3): 209-221

ISSUE DATE:

1977-11-30

URL:

http://hdl.handle.net/2433/175951

RIGHT: 


\title{
SOME GONSIDERATION ON VOMERINE TEETH AND VOMERINE PROTUBERANCE IN THE GOBIID FISH ${ }^{\text {) }}$
}

\author{
YASUNOBU YANAGISAWA \\ Seto Marine Biological Laboratory
}

With Text-figures 1-9 and Tables 1-3

Presence of the vomerine teeth has been regarded to be relatively important as the taxonomical character in various groups of Osteichthyes. Among the gobiid fish, the genus Bostrichthys Duméril (1806) has been known for long to have a lot of small conical teeth on the vomer, by which it is separated from the other genera of Eleotridae. In Gobiidae, Jordan and Seale (1906) and Herre (1933) recognized teeth on the vomer, which are not conical but large blunt wide teeth, in Mars strigilliceps and $M$. caeruleomaculatus respectively. Later, Herre described many species with the vomerine teeth of this type and subsequently established many genera from 1934 to 1953 from the Philippines and other tropical waters of the Pacific.

In the course of my study on the association between the gobiid fish and the snapping shrimp, I collected 21 species of the gobiid fish from the southern coast of Japan which were dwelling in the burrow made by the shrimps. Two species of them were assigned to Smilogobius singapurensis and Mars caeruleomaculatus. These species have been pointed out by Herre $(1933,1936)$ to have the vomerine teeth, but, in my specimens, I could not find any vomerine teeth in both species, although their frontal part of the vomer looked like to project downward more noticeably than the other common gobies. After examination of Herre's paratypes of these species, it became clear that the vomerine teeth pointed out by Herre is nothing but a downward protuberance of the frontal part of the vomer. Moreover, such a vomerine protuberance was proved to exist, more or less, in many other species of the gobiid fish.

In this paper, the nature of the vomerine protuberance is examined and discussed, in relation to the vomerine teeth, on the specimens of gobiid fishes available, as well as basing on the descriptions in the literatures.

I would like to express my sincere thanks to Dr. Eiji Harada of our laboratory for his critical reading of the manuscript. Thanks are also due to Dr. William N. Eschmeyer of California Academy of Science for giving me a chance to examine some types of Herre's species. I am also grateful to Mr. Chuichi Araga of our laboratory and to Mr. Tetsuo Yoshino of University of the Ryukyus for lending me specimens of Smilogobius singapurensis from Ishigaki Islands, and to Mr. Kazuyuki Suzuki for lending me specimens of Bostrichthys sinensis from Ishigaki Island.

1) Contributions from the Seto Marine Biological Laboratory, No. 641.

Publ. Seto Mar. Biol. Lab., XXIV (1/3), 209-221, 1977.

(Article 16) 
The Vomerine Teeth of Herre.

The vomerine teeth which Herre attributed to the species and genera, 17 and 11 in Gobiidae and 2 and 2 in Eleotridae respectively, described and established by him on the specimens from the Philippines and other tropical Pacific (1933, 1934, $1936,1943,1945,1950,1953 a, 1953 b)$, are not canine-like or conical teeth, but are incisor-like teeth (Table 1). He expresses himself of the vomerine teeth, for example, as "two large wide teeth" in Mars caeruleomaculatus, "the enormous vomerine teeth coalesce into a unit by their inner edges" in Smilogobius singapurensis, "two enormous solid incisors side by side" in Macrodontogobius wilburi and "a pair of very large incisors, fused into a single chisel-like mass" in Mindrogobius lopezi.

Among the specimens of gobiid fish at my disposal, which were collected in the Nansei Islands, there are 14 and 11 specimens that can be assigned to Smilogobius singapurensis and Mars caeruleomaculatus respectively in almost all characteristics described by Herre $(1933,1936)$. In these specimens, however, there is merely a large downward projection on the frontal part of the vomer, instead of apparent teeth.

Fortunately, I had a chance to examine the paratypes of $S$. singapurensis from the reef in Singapore Harbor and $M$. caeruleomaculatus from Sulu Province, Philippine. My specimens mentioned above agree well with these paratypes of respective species in the meristic and proportional characters (Table 2). These paratypes also bear

Table 1. A list of the gobiid fish with vomerine teeth established by Herre.

\begin{tabular}{lc} 
species & year \\
\hline Gobiidae & 1933 \\
Mars caeruleomaculatus & 1936 \\
M. haydeni & 1934 \\
Smilogobius inexplicatus & 1934 \\
S. obliquus & 1936 \\
S. cinctus & 1936 \\
S. singapurensis & 1934 \\
Myersina macrostoma & 1936 \\
Macrodontogobius wilburi & 1943 \\
Mangarinus waterousi & 1943 \\
Intonsagobius kuderi & 1950 \\
I. vanclevei & 1945 \\
Coronogobius striatus & 1945 \\
Mindrogobius lopezi & 1945 \\
Calamiana magnoris & 1953 \\
Thalassogobius corrallinus & 1953 \\
Pallidogobius rigilius & 1953 \\
Bikinigobius welanderi & \\
Eleotridae & 1953 \\
Gracileotris bockensis & 1953 \\
Zebreleotris fasciata &
\end{tabular}


Table 2. Counts and measurements of paratypes of Smilogobius singapurensis and Mars caeruleomaculatus, and specimens of two species from the Nansei Islands. Measurements are expressed in thousands of standard length. Transverse scales are counted from the anal origin upward and backward to the base of second dorsal fin.

\begin{tabular}{|c|c|c|c|c|}
\hline & \multicolumn{2}{|c|}{ Smilogobius singapurensis } & \multicolumn{2}{|c|}{ Mars caeruleomaculatus } \\
\hline & Paratypes SU 16963 & $\begin{array}{l}\text { Specimens* from Nansei } \\
\text { Islands }\end{array}$ & Paratypes SU 16959 & $\begin{array}{l}\text { Specimens** from Nansei } \\
\text { Islands }\end{array}$ \\
\hline Number of specimens & 3 & 14 & 2 & 11 \\
\hline $\operatorname{Sex}(q+\delta)$ & $2+1$ & $9+5$ & $1+1$ & $6+5$ \\
\hline Standard length $(\mathrm{mm})$ & $59.0-78.9(70.0)$ & $58.6-81.7(67.0)$ & $35.4,37.6$ & $30.8-40.7(35.2)$ \\
\hline Dorsal fins & VI-I, 10 (in 3) & VI-I, 9 (in 1 ), 10 (in 12 ), 11 (in 1$)$ & VI-I, 10 (in 2) & VI-I, 9 (in 1$), 10$ (in 10$)$ \\
\hline Anal fin & I, 10 (in 3 ) & $1,10$ (in 12$), 11$ (in 2$)$ & I, 9 (in 9$)$ & I, 8 (in 1$), 9($ in 10$)$ \\
\hline Pectoral fins & 16 (in 1$), 17$ (in 4$), 18$ (in 1$)$ & 16 (in 4$), 17$ (in 18), 18 (in 6) & 16 (in 1$), 17$ (in 3 ) & 16 (in 15$), 17$ (in 6 ) \\
\hline Longitudinal scales & $77-93(83)$ & $71-89(80)$ & 52,55 & $58-65(60)$ \\
\hline Transverse scales & $25-26(26)$ & $24-29(27)$ & 20,21 & $18-21(20)$ \\
\hline Head length & $270-297(281)$ & $254-300(284)$ & 309,325 & $289-320(307)$ \\
\hline Body height & $194-212(200)$ & $172-198(189)$ & 223,249 & $197-224(211)$ \\
\hline Eye diameter & $61-71(67)$ & $57-67(61)$ & 69,73 & $64-75(69)$ \\
\hline Snout length & $82-90(86)$ & $74-98(88)$ & 74,82 & $65-86(78)$ \\
\hline Caudal peduncle height & $98-105(102)$ & $97-108(102)$ & 112,119 & $105-117(109)$ \\
\hline Caudal length & $283-3$ I9 (302) & $283-319(300)$ & 299,301 & $234-328(287)$ \\
\hline
\end{tabular}

* From sandy mud bottom at depths of less than $1 \mathrm{~m}$ in Kabira Bay, Ishigaki Island, on 14 and 15 February 1973 by me and on 11 July 1973 by Araga and Yoshino.

** From sandy mud or mud bottom at depths of less than $2 \mathrm{~m}$ at Hakebina Beach, Yoron Island on 13 November 1972 , in Akasaki

Reef, Yoron Island on 12 July 1973, at Kametoku, Tokunoshima Island on 2 and 5 November 1973, and at Chinasaki, Okinawa

Island on 19 October 1974 by me. 
a projection on the vomer that is quite similar to that in the specimens concerned. There seems to be no doubt in that what Herre called the vomerine teeth means a frontal projection on the vomer.

Whether this projection on the vomer is derived from true teeth or is merely a part of the vomer is another matter. I have examined the vomerine projection with alizarine-red stain on some specimens of both species from the Nansei Islands. Fig. 1 and Fig. 2 show the shape of the vomer of $S$. singapurensis and $M$. caeruleomaculatus respectively. The vomer of $S$. singapurensis is connected with the mesethmoid with a pair of ascending processes at its dorso-frontal part; the frontal part is triangular in a ventral view and noticeably projecting downward along the frontal edge; the form of the projection is like a chisel in a frontal view; the projection is stained with alizarine-red as the other part of the vomer, suggesting no histological differences between the projection and the other part of the vomer. The shape of the vomer of $M$. caeruleomaculatus is similar to that of $S$. singapurensis, but its projection is not so noticeable as in the latter; the projection and the other part of the vomer are equally stained with alizarine-red. From these results, it is obvious that the projection on the vomer is not a structure made of true teeth but is merely a protuberance of the frontal part of the vomer at least in the case of these two species.
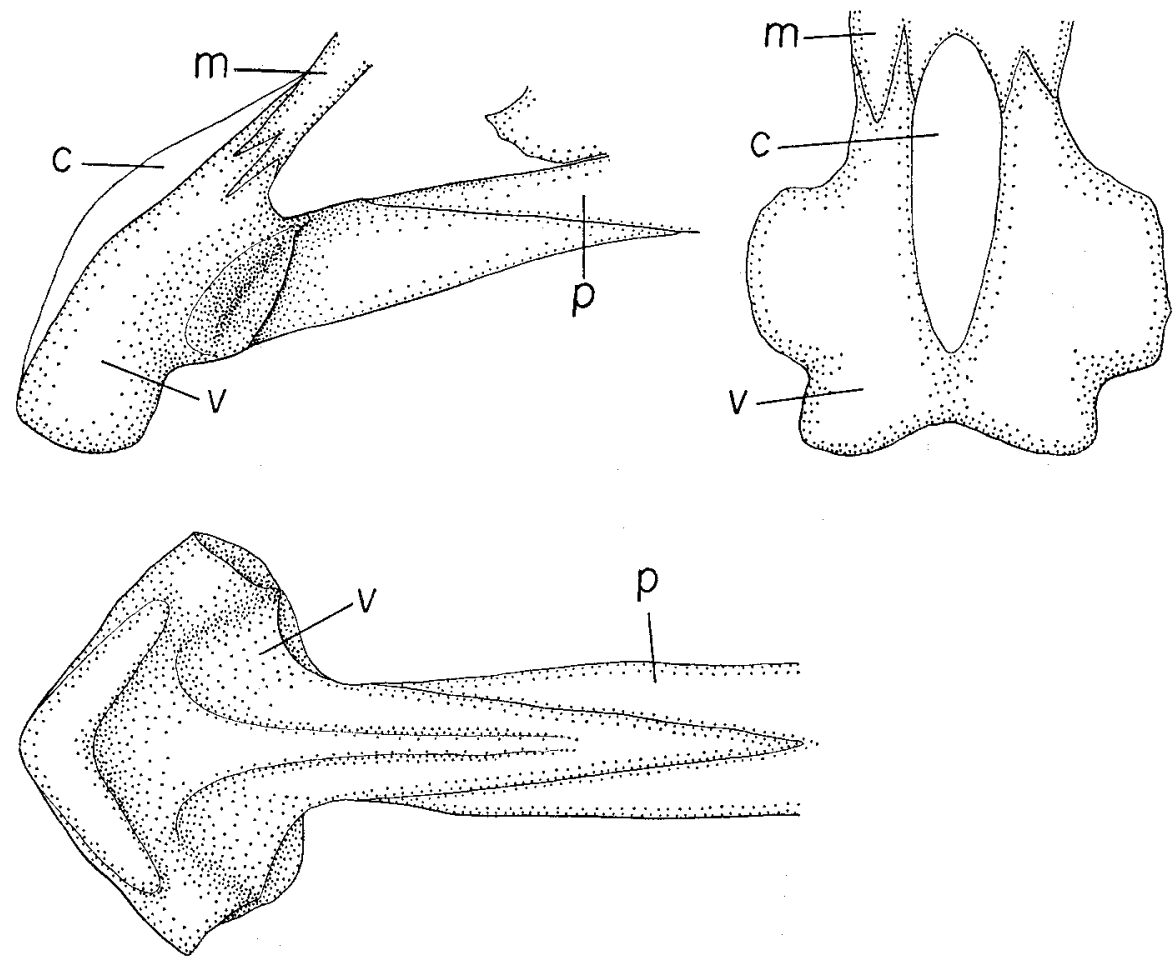

Fig. 1. Vomer of Smilogobius singapurensis (female, $61.8 \mathrm{~mm}$ in standard length). Upper left is lateral view, upper right frontal view and lower left ventral view. c: cartilage, $\mathrm{m}$ : mesethmoid, $\mathrm{p}$ : parasphenoid, $\mathrm{v}$ : vomer, $\mathrm{vt}$ : vomerine teeth. 

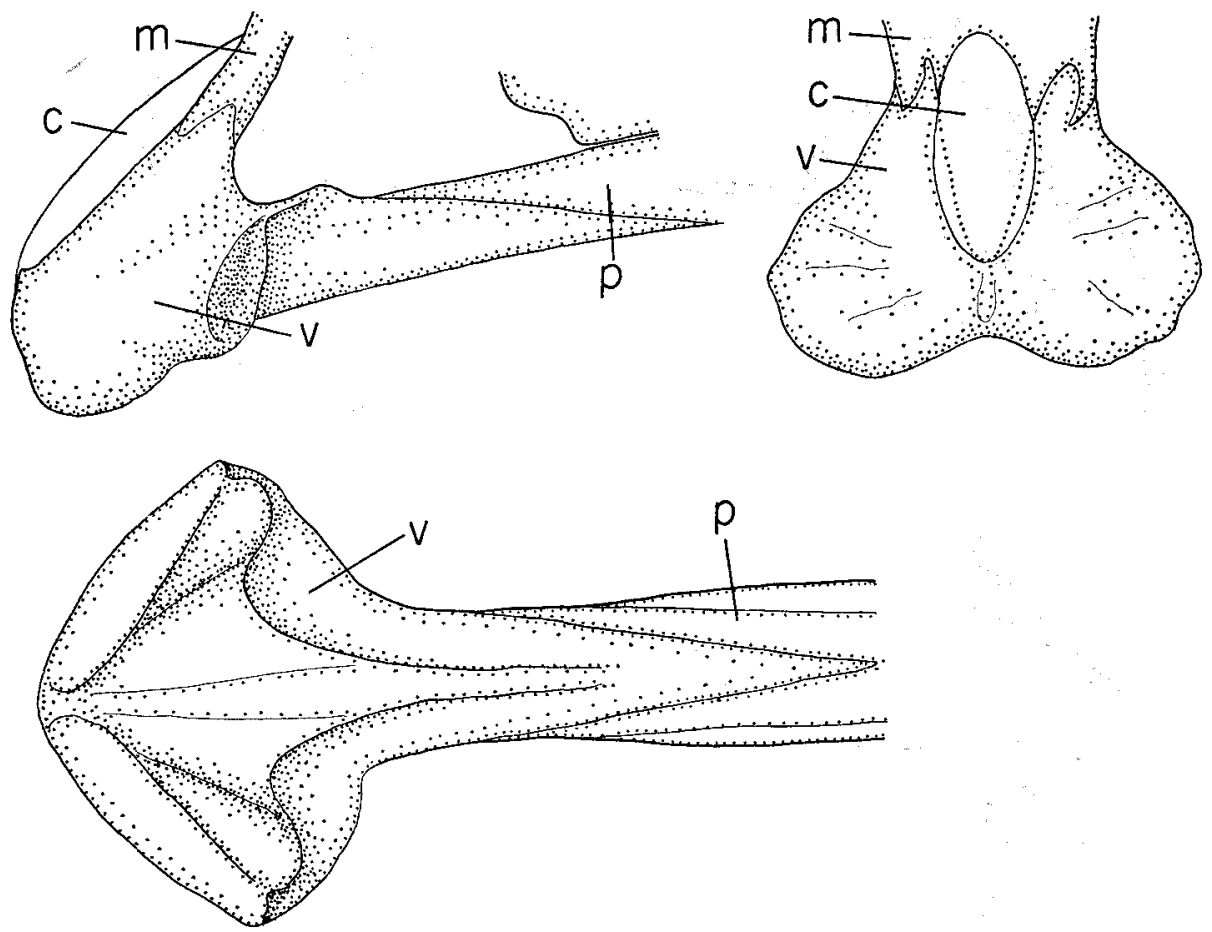

Fig. 2. Vomer of Mars caeruleomaculatus (female, $35.6 \mathrm{~mm}$ in standard length).

\section{The Degree of Development of the Vomerine Protuberance in the Gobiid Fishes.}

Although Herre referred to the vomerine teeth, probably of the nature of a vomerine protuberance, no other workers have ever investigated the vomerine protuberance as a character of taxonomical importance in the gobiid fish. In this connection, I examined the vomer in another four species, Cryptocentrus filifer, Obtortiophagus sp., Valenciennea longipinnis and Rhinogobius brunneus, and also checked briefly the degree of development of the vomerine protuberance by observing it through the mouth opening on another 32 species at hand.

The vomer of Cryptocentrus filifer (Fig. 3) is connected with the mesethmoid with a pair of ascending processes at its dorso-frontal part; the frontal part is triangular in a ventral view and projecting downward along the frontal edge; the degree of development of the portuberance is less than in Smilogobius singapurensis and its tip is slightly pointed. The shape of the vomer and degree of development of the protuberance of Obtortiophagus sp. (Fig. 4) are very similar to those of Mars caeruleomaculatus, though its vomer is wider than that of the latter. The vomer of Valenciennea longipinnis (Fig. 5) is greatly different from that of $S$. singapurensis or $M$. caeruleomaculatus; the vomer has no ascending processes and is not connected with the mesethmoid, and the cartilage occupies the space between those two bones; the protuberance is fairly large along the frontal edge. The vomer of Rhinogobius brunneus (Fig. 6) is depressed and far apart from the mesethmoid and the interspace is occupied 

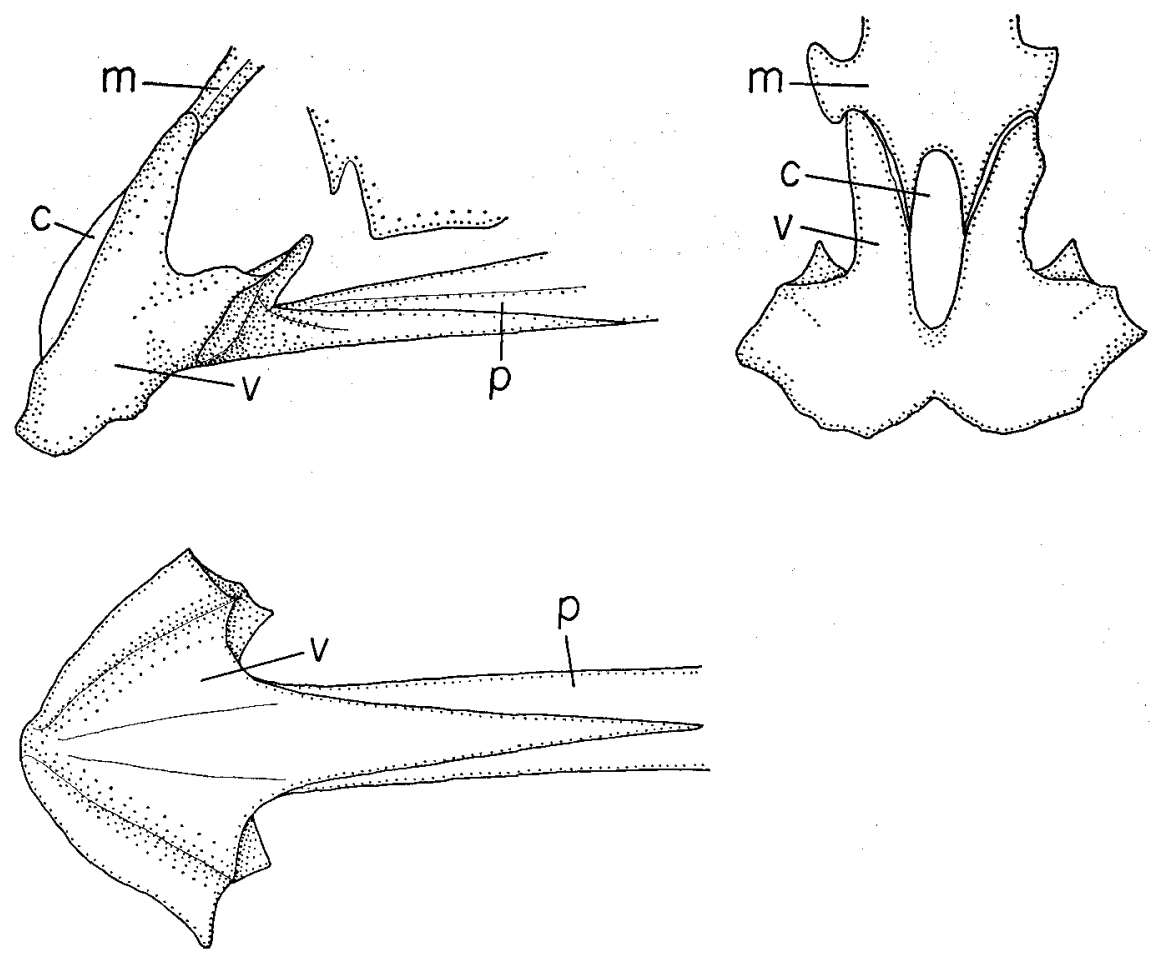

Fig. 3. Vomer of Cryptocentrus filifer (male, $59.1 \mathrm{~mm}$ in standard length).
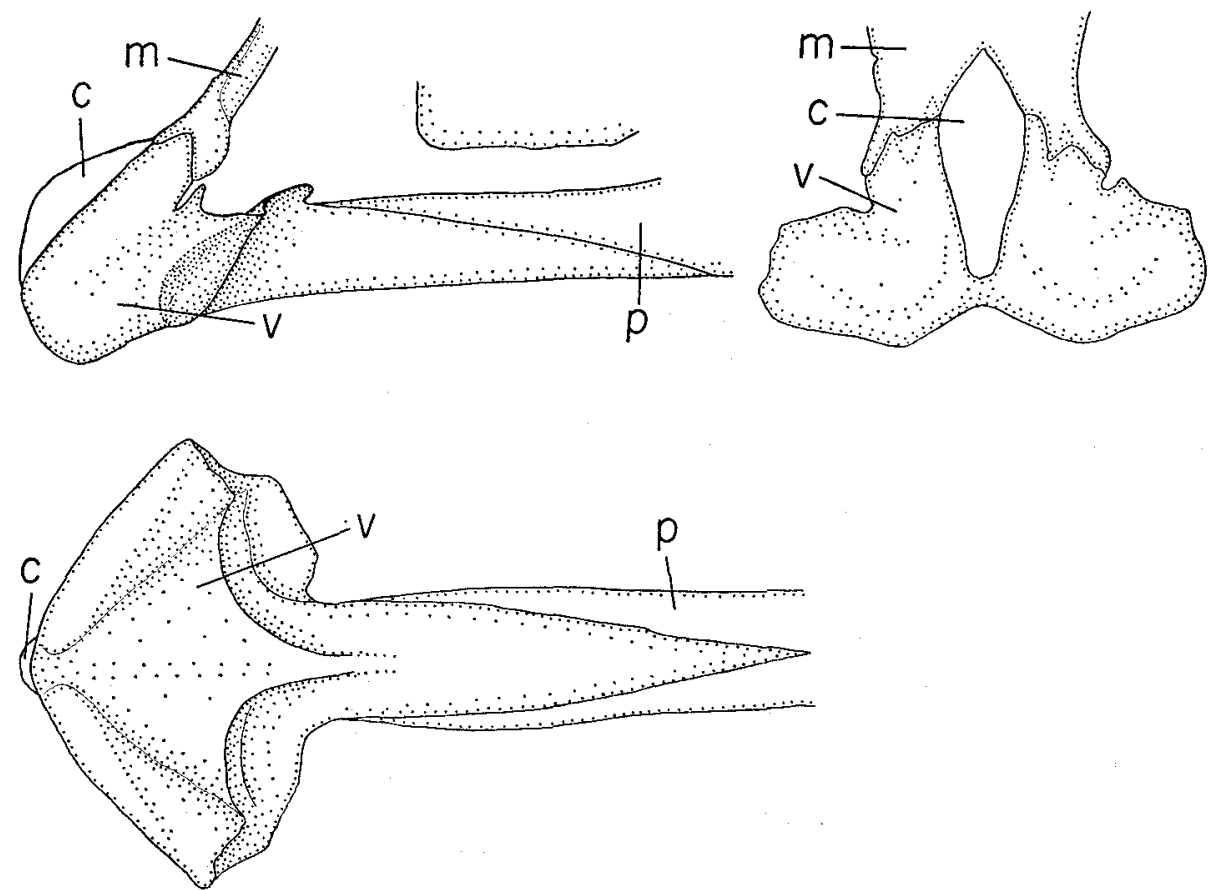

Fig. 4. Vomer of Obtortiophagus sp. (female, $64.0 \mathrm{~mm}$ in standard length). 

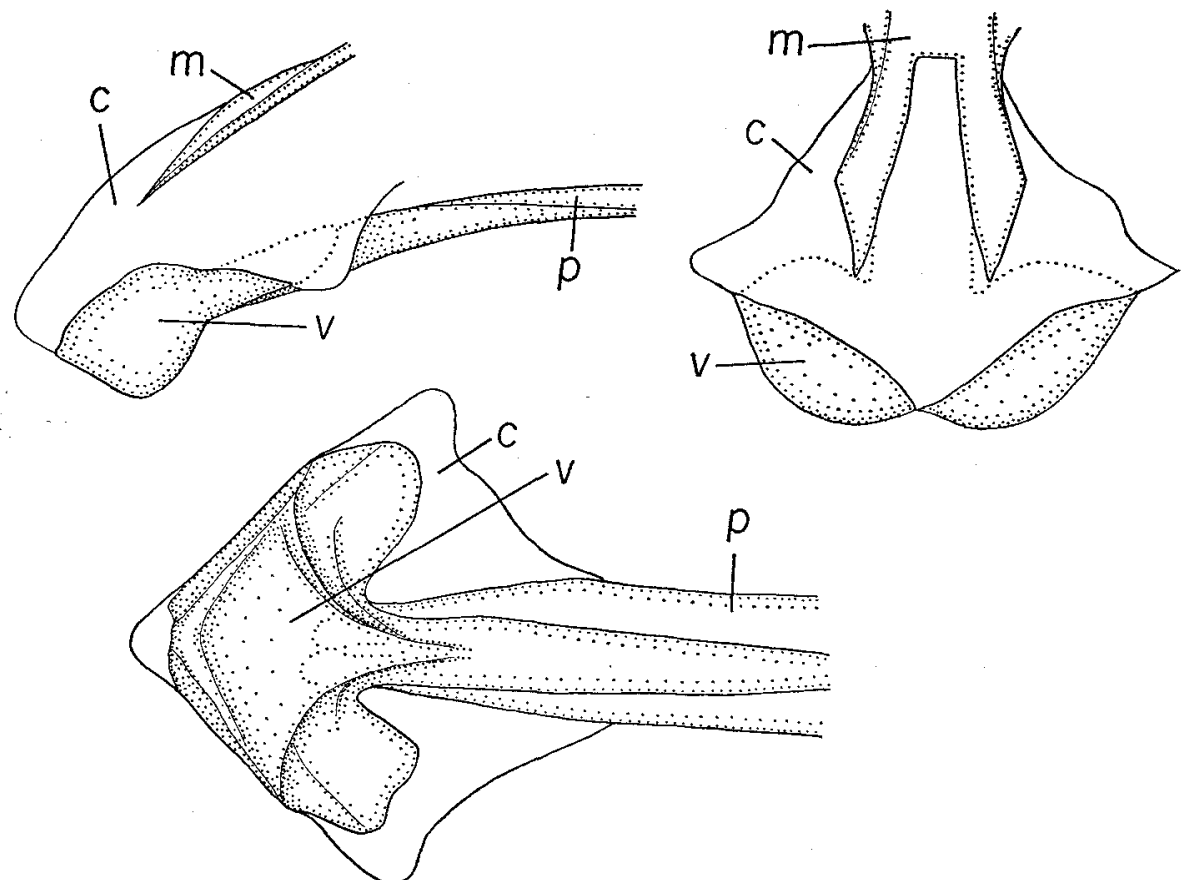

Fig. 5. Vomer of Valenciennea longipinnis (male, $59.9 \mathrm{~mm}$ in standard length).
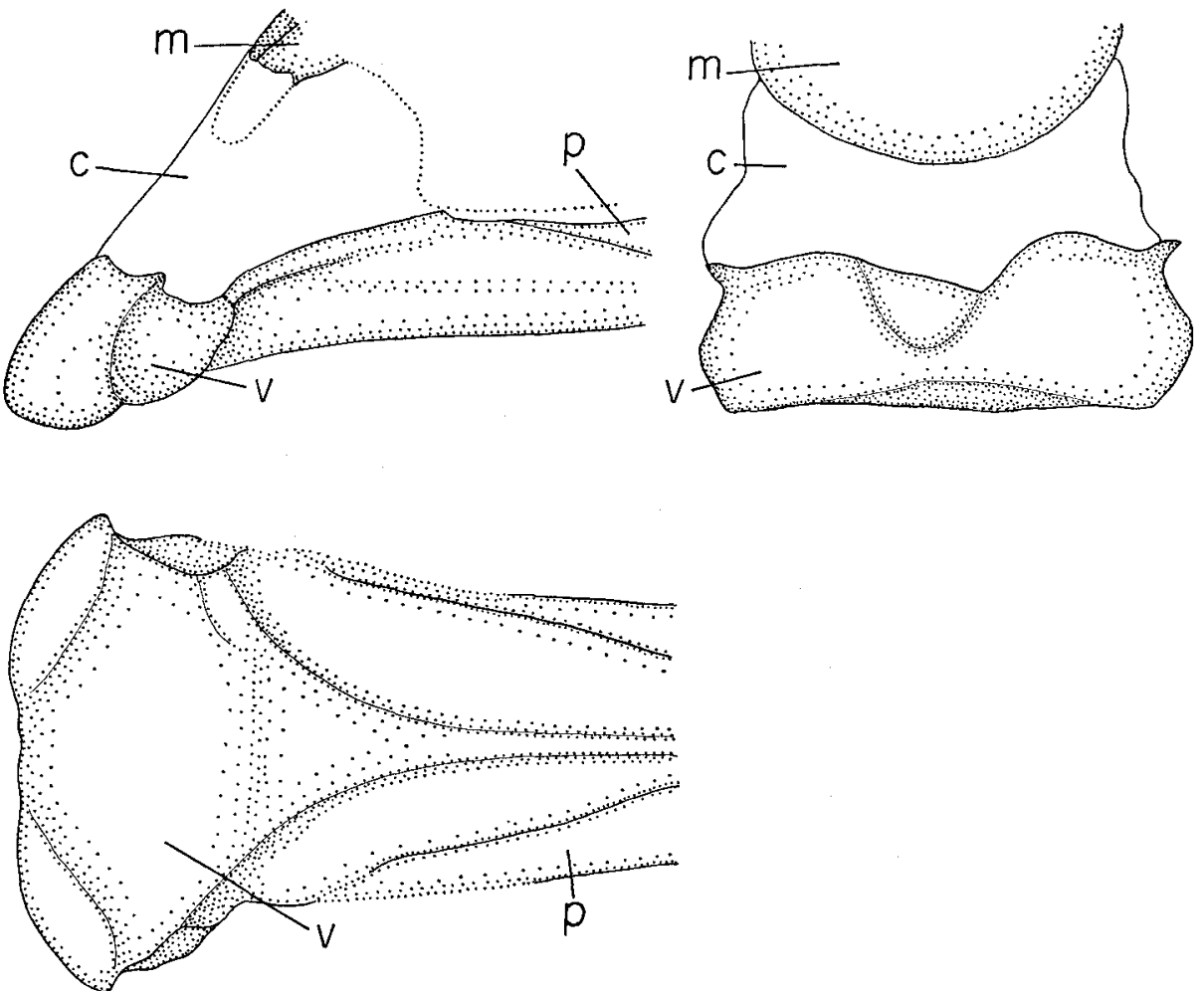

Fig. 6. Vomer of Rhinogobius brunneus (female, $60.9 \mathrm{~mm}$ in standard 1ength). 
by the well-developed cartilage; the protuberance is negligible. The shape of the vomer and the degree of development of the protuberance are much varied among the species examined, and the well-developed protuberance is recognized even in the species having the vomer of the different types, as seen in $S$. singapurensis and $V$. longipinnis.

The results of observation of the vomerine protuberance is shown in Table 3 .

Table 3. The degree of development of vomerine protuberance observed through mouth opening. H: remarkably developed as in Smilogobius singapurensis, H: fairly developed as in Mars caeruleomaculatus, +: only slightly developed, - : no protuberance is detected.

\begin{tabular}{|c|c|c|}
\hline species & degree & \\
\hline Acanthogobius flavimanus (Temminck et Schlegel) & - & \\
\hline Acentrogobius campbelli (Jordan et Synder) & + & \\
\hline A. cringer (Cuvier et Valenciennes) & + & \\
\hline A. pflaumi (Bleeker) & + & \\
\hline Amblyeleotris fasciata (Herre) & + & \\
\hline A. japonica Takagi & + & \\
\hline A. maculata Yanagisawa & + & \\
\hline Amblyeleotris sp. & + & \\
\hline Amblyogibus albimaculatus (Rüppell) & H & \\
\hline A. hectori (Smith) & $H$ & \\
\hline Bathygobius fuscus (Rüppell) & - & \\
\hline Bostrichthys sinensis (Lacepède) & -- & \\
\hline Chasmichthys dolichognathus gulosus (Guichenot) & + & \\
\hline Cryptocentrus flifer (Cuvier et Valenciennes) & $H$ & \\
\hline Tomiyamichthys oni (Tomiyama) & - & \\
\hline (?) Cryptocentrus sp. & H & \\
\hline Ctenogobiops maculosus (Fourmanoir) & $H$ & \\
\hline Eleotris oxycephala Temminck et Schlegel & - & \\
\hline Fusigobius neophytus (Günther) & - & \\
\hline Mahidolia mystacina (Cuvier et Valenciennes) & HH & \\
\hline Mars caeruleomaculatus Herre & H & \\
\hline Obtortiophagus sp. 1 & + & \\
\hline Obtortiophagus sp. 2 & + & \\
\hline Parachaeturichthys polynema (Bleeker) & + & \\
\hline Periophthalmus cantoneneis (Osbeck) & - & \\
\hline Ptereleotris evides (Jordan et Hubbs) & H & \\
\hline Rhinogobius brunneus (Temminck et Schlegel) & + & \\
\hline Sicyopterus japonicus (Tanaka) & + & \\
\hline Smilogobius singapurensis Herre & H & \\
\hline Smilogobius sp. & H & \\
\hline Valenciennea helsdingeni (Bleeker) & \# & \\
\hline$V . \quad$ longipinnis (Bennet) & H & \\
\hline V. puellaris (Tomiyama) & H & \\
\hline V. strigatus (Broussonet) & H & \\
\hline Valenciennea $\mathrm{sp}$ & Ht & . \\
\hline Vanderhorstia mertensi Klausewitz & Ht & \\
\hline V. ornatissima Smith & + & \\
\hline Vanderhorstia sp. & 一 & \\
\hline
\end{tabular}


About two thirds of 38 species have slightly or not developed vomerine protuberance, e.g., Eleotris oxycephara, Amblyeleotris japonica, Rhinogobius brunneus, Bathygobius fuscus and Periophthalmus cantonensis. However, the well-developed protuberance was recognizable in various species; the development of the protuberance in Ptereleotris evides and Ctenogobiops maculosus is fairly remarkable, and, in addition to Smilogobius singapurensis and Valenciennea longipinnis, Smilogobius sp., Vanderhorstia mertensi, Mahidolia mystacina, Amblygobius albimaculatus, A. hectori, Valenciennea strigatus, V. puellaris, $V$. helsdingeni and Valenciennea sp. have the most developed protuberance. In the three species of the genus Vanderhorstia, the degree of development differs from one another; that of Vanderhorstia sp. is negligible and V. ornatissima has a small one, but V. mertensi has large one. On the other hand, in the genus Valenciennea, all the five species examined have a wide large protuberance. Two species of the genus Amblygobius examined also have a developed one. The degree of development may be variable even in one genus in some cases, but in other cases, may be stable in one taxonomical group.

Possible Synonymies of Genera having the Vomerine Protuberance.

The vomerine teeth mentioned by Herre became clear to be nothing but a vomerine protuberance, and such a protuberance is more or less recognizable in many gobies and its degree of development is variable even within one genus. So, it is not appropriate to establish new genera by putting too much stress on the presence of a vomerine protuberance. Therefore, other characteristics attributed to the genera established by Herre as having the "vomerine teeth", that is, a vomerine protuberance, should be reexamined.

The genus Smilogobius Herre (1934) has the following characters: 70 to 85 cycloid scales in a longitudinal series, the body is naked back to the pectoral and ventral bases and dorsal origin, or there may be a few very small scales above the opercle; 3 or 4 rows of minute teeth are in the upper jaw and a short outer row of enlarged teeth, or 2 or 3 pairs of caniniform teeth; the lower jaw has 3 to 5 rows of small teeth and may bear a pair of stout canines laterally; interorbital is very narrow. These characters agree with those of the genus Cryptocentrus very well. The similarities between Smilogobius and Cryptocentrus were already mentioned by Klausewitz (1960): "Es ist möglich, daß das von Roux-Estève (1956) als Smilogobius singapurensis bestimmte Stück nicht zu dieser Art sondern zu Cryptocentrus lutheri gehört. Auf jeden Fall besteht zwischen beiden Formen eine recht erstaunliche Ähnlichkeit. Da unserem Stück die für Smilogobius charakteristischen beiden Incisivi fehlen, kann es auf keinen Fall zu dieser Gattung gerechnet werden." The vomerine protuberance, which is developed well in Smilogobius, may be also recognizable in Cryptocentrus such as in $C$. filifer (Fig. 3), though no attention has been given to the shape of the vomer in any species of Cryptocentrus. As the similarities between them are thorough and the good development of the vomerine protuberance seems not to be restricted to the former, the genus Smilogobius cannot be separated from the genus Cryptocentrus.

As mentioned by Herre (1936) himself, the genus Macrodontogobius "has the 
general aspect of Gnatholepis, but differs in having two enormous solid incisors side by side on the vomer, extending clear across the roof of the mouth". This genus undoubtedly resembles Gnatholepis, but it is allied more closely to the genus Acentrogobius, because of having the restricted gill opening, scarcely wider than the pectoral base, and the broad isthmus, instead of the wide gill opening and the narrow isthmus (Koumans, 1953; Smith, 1959). The genus Macrodontogobius may probably become a synonym of the genus Acentrogobius if the vomerine protuberance is not regarded as a generic character.

The genus Intonsagobius Herre (1943) with "two broad incisors on the vomer" has "broad and thickset head" and "many well-developed transverse and longitudinal fringed ridges, bearing conspicuous rows of sensory papillae" on head. This genus agree well with the genus Callogobius in many features as being said by Herre himself and seems to become a synonym to the latter, if the vomerine protuberance is not regarded as a generic character.

The genus Zebreleotris Herre (1953) is a synonym of the genus Amblyeleotris as mentioned in my previous paper (Yanagisawa, 1976).

Some of the other genera with the "vomerine teeth" established by Herre may be found, too, to be the synonym of the previously established genera, when Herre's descriptions and types are closely reexamined.

\section{True Vomerine Teeth in the Gobiid Fish.}

As the genus Smilogobius and other genera with the vomerine teeth established by Herre became clear to have no true teeth on the vomer, the genus Bostrichthys is the only goby hitherto known to have true vomerine teeth. However, I recently
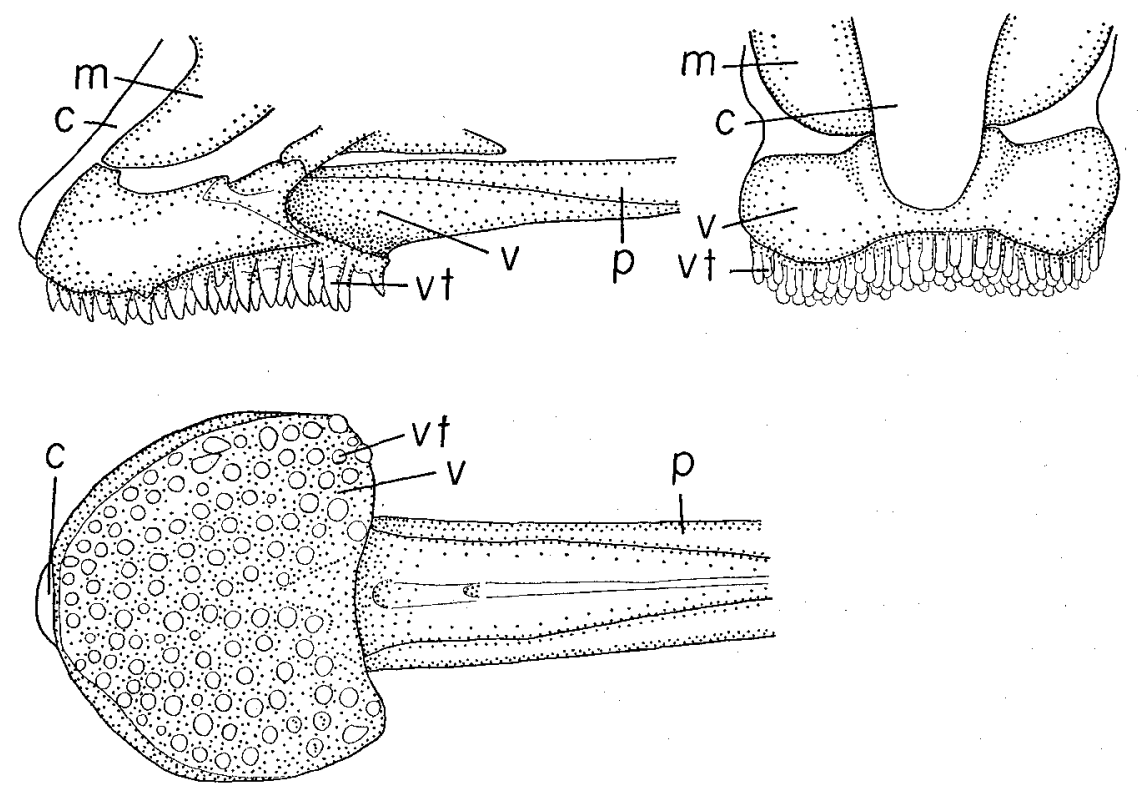

Fig. 7. Vomer and vomerine teeth of Bostrichthys sinensis (female, $94.5 \mathrm{~mm}$ in standard length). 
found another species with the true vomerine teeth collected at Shirahama, which closely resembles the genus Cryptocentrus or may be assigned to Cryptocentrus.

Four species have been known in Bostrichthys in the Indo-Pacific waters (Koumans, 1953). In Japan, one species B. sinensis is known to be distributed in the sea and the river in the Nansei Islands (Tomiyama, 1936; Masuda et al., 1975; Yoshino et al., 1975). As shown in Fig. 7, the vomer of B. sinensis is connected with the mesethmoid at its dorso-frontal part; the frontal part is semicircle in shape and not noticeably projecting downward; its undersurface is flat, bearing a patch of many small teeth; the form of teeth is nearly conical, their tips are pointed in a lateral view, but roundish in a frontal view.

Three specimens (21.2, 40.7 and $37.0 \mathrm{~mm}$ in standard length) of undescribed species having a closest affinity with Cryptocentrus were caught from sandy bottom with coral rubble and pebbles at 3 to $4 \mathrm{~m}$ depth, Shirahama, Wakayama Pref., 29 April and 26 August 1973, 11 July 1976 (Fig. 9c). This species is associating with Alpheus bellulus. By observing the vomer through the mouth opening, we can see a large vomerine protuberance with a wide notch at the middle (Fig. 8). Each side of the protuberance has 1 to 4 large canine-like teeth projecting downward, though they are not fully developed in a young specimen. The shapes of the vomer and the vomerine teeth of this species are qiute different from those of $B$. sinensis. The presence of the true teeth on the protuberance in this species composes another evidence for the view that the protuberance is not a structure made of true teeth.

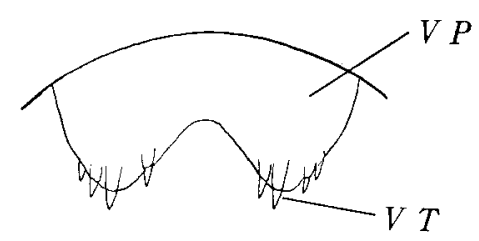

Fig. 8. Diagrammatic figure of vomerine protuberance and vomerine teeth of (?) Cryptocentrus sp. (SMBL-F 73044, female, $40.6 \mathrm{~mm}$ in standard length) in a frontal view.

vp: vomerine protuberance, vt: vomerine teeth.

\section{Conclusion}

In the case of the genera Valenciennea and Amblygobius, all the species examined in this study have a large protuberance on the vomer. All of them make a burrow under flat dead coral or big stone embedded in the sand bottom by swallowing and spewing the sand with their mouths, except $A$. hector $i$ whose ecology has not been known, and when these fishes are outside their burrows, they do not lie on the bottom, but hover above the bottom. To take large mouthfuls of sand is also feeding behaviour in these genera (Hoese et Allen, 1977). The commonness of the welldeveloped protuberance and the mode of life in these species probably suggests that a function of the protuberance may be related to burrowing and feeding behaviour if the protuberance should really have some functions.

However, as has been stated elsewhere, the well-developed vomerine protuberance 

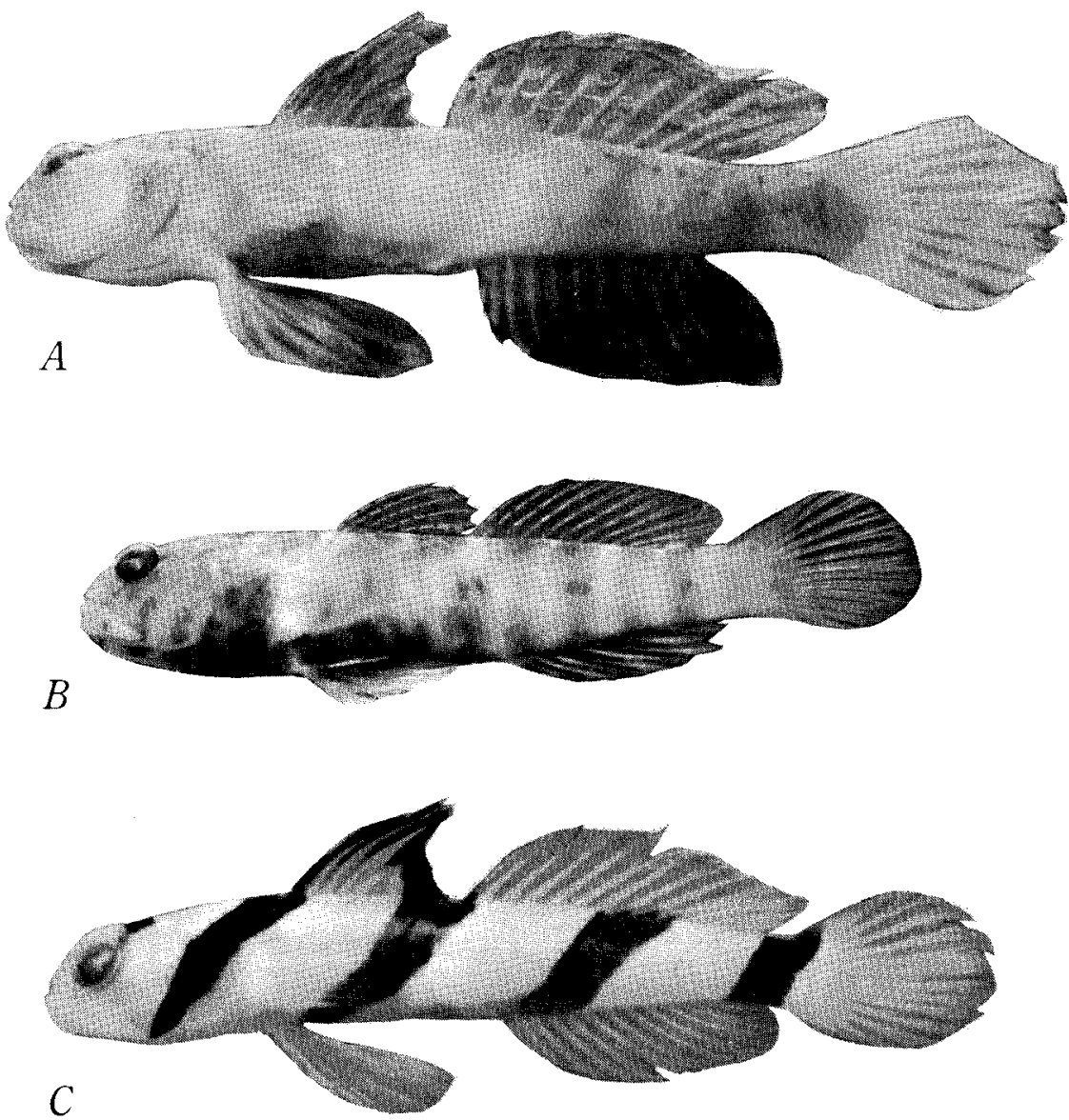

Fig. 9. Specimens of (A) Smilogobius singapurensis (SMBL-F 73134, male, $70.6 \mathrm{~mm}$ in standard length, Kabira Bay, Ishigaki Island), (B) Mars caeruleomaculatus (SMBL-F 73424, female, $36.7 \mathrm{~mm}$ in standard length, Kametoku, Tokunoshima Island) and (C) (?) Cryptocentrus sp. (SMBL-F 73044, female, $40.7 \mathrm{~mm}$ in standard length, Shirahama, Wakayama Pref.).

is recognized in the various groups of the gobiid fish, and the great variation of development are seen even among the species belonging to the same genus, as seen in Vanderhorstia. The form of the vomer is also variable; for example, the vomer of Smilogobius singapurensis has a pair of ascending processes and is connected with the mesethmoid, but that of Valenciennea longipinnis lacks these processes and is far apart from the mesethmoid, though both species have well-developed protuberance. These facts seem to suggest that the protuberance was developed independently in the various groups. As for the true vomerine teeth, they must also be considered to have been developed independently in the two groups dealt in this study, as the genus Bostrichthys which has been considered one of the most primitive gobiid fish (Akihito et Meguro, 1974) and the undescribed species having the closest affinities with Cryptocentrus are taxonomically separated far away from each other, and have 
different types of the vomerine teeth; a patch of small conical teeth in the former (Fig. 7) and 1 to 4 canine-like teeth on each side of a notched protuberance in the latter (Fig. 8). It seems to me at present that the development of the vomerine protuberance and the presence of the true vomerine teeth are affected by the mode of life of the fishes more closely than the phylogeny of the gobiid fish. These characteristics need to be examined in further more species of the gobiid fish to evaluate the taxonomical importance of them.

\section{REFERENGES}

Akihito, Prince, and K. Meguro, 1974. On Gobiid fishes Ophiocara porocephala and Ophieleotris aporos. Jap. J. Ichthyol., 21 (2) : 72-84. (In Japanese).

Herre, A.W. 1933. Twelve new Philippine fishes. Copeia, 1933 (1): 17-25.

1934. Notes on fishes in the Zoological Museum of Stanford University. I. The fishes of the Herre Philippine expedition of 1931. Fish. Herre Philip. Exped. 1931. Hong Kong. 106 pp. 1936. Eleven new fishes from the Malay Peninsula. Bull. Raffles Mus. Singapore, 12: 5-16. - 1943. Notes on fishes in the Zoological Museum of Stanford University. XI. Two new genera and species, with key to the genera of gobies with vomerine teeth. Proc. Biol. Soc. Wash., 56: $91-96$.

1945. Notes on fishes in the Zoological Museum of Stanford University. XIX. Two new Philippine gobies, with key to the genera of gobies with vomerine teeth. Ibid., 58: 77-82. 1950. Two new gobies from the Philippines with notes on a third rare goby. Ibid., 63: 7376.

1953a. Tropical Pacific gobies with vomerine teeth. Philip. J. Sci., 82 (2): 181-188.

1953b. The tropical Pacific Eleotridae with vomerine teeth with descriptions of two new genera and two new species from the Marshall Islands. Ibid., 82 (2): 189-192.

Hoese, D.F. and G.R. Allen, 1977. Signigobius biocellatus, a new genus and species of sand-dwelling coral reef gobiid fish from the western tropical Pacific. Jap. J. Ichthyol., 23 (4): 199-207.

Jordan, D.S. and A. Seale, 1906. The fishes of Samoa. Descriptions of species found in the archipelago, with a provisional check-list of the fishes of Oceania. Bull. Bur. Fish., 24: 173-445.

Klausewitz, W. 1960. Fische aus dem Roten Meer. IV. Einige systematisch und ökologisch bemerkenswerte Meergrundeln (Pisces, Gobiidae). Senck. biol, 41 (3/4): 149-162.

Koumans, F.P. 1953. Gobioidea. The fishes of the Indo-Australian Archipelago, X. xiii +423 pp., 95 figs., Leiden.

Masuda, H., C. Araga and T. Yoshino, 1975. Coastal fishes of southern Japan. 379 pp., 143 pls., 11 figs. Tokyo.

Smith, J.L.B. 1959. Gobiid fishes of the families Gobiidae, Periophthalmidae, Trypauchenidae, Taenioididae, and Kraemeriidae of the Western Indian Ocean. Ichthyol. Bull. Rhodes Univ. 13: $185-225$.

Tomiyama, I. 1936. Gobiidac of Japan. Jap. J. Zool., 7: 37-112.

Yanagisawa, Y. 1976. Genus Amblyeleotris (Gobiidae) of Japan and geographical variations of $A$. japonica Takagi. Publ. Seto Mar. Biol. Lab., 23 (1/2): 145-168.

Yoshino, T., S. Nishijima and S. Shinohara, 1975. Catalogue of fishes of the Ryukyu Islands. Bull. Sci. \& Eng. Div., Univ. Ryukyus. (Math. \& Nat. Sci.) 20: 61-118. (In Japanese). 